\title{
Pseudosection modeling and zircon geochronology of barroisite eclogites from the Antarctic Ross orogen
}

\author{
TAEHWAN KIM ${ }^{1}$
}

${ }^{1}$ Korea Polar Research Institute, Republic of Korea (taehwan.kim@kopri.re.kr)

I investigated pristine barroisite eclogites from the Ross orogen, Antarctica. Mineral assemblages are represented by garnet + omphacite + calcic/sodic-calcic amphibole + epidote + phengite + paragonite + rutile + quartz. These eclogites revealed three stages of prograde metamorphism, defining two distinctive $P-T$ trajectories, $\mathrm{M}_{1-2}$ and $\mathrm{M}_{3}$. The $P-T$ pseudosections were calculated in the (Mn)NCKFMASHO model system. The $P-T-\mathrm{M}_{\mathrm{H} 2 \mathrm{O}}$ relationship suggests that higher amounts of $\mathrm{H}_{2} \mathrm{O}$ are required for the $\mathrm{M}_{1}$ assemblages, in which hydrous phases are stable, than those for the $\mathrm{M}_{2}$. The $\mathrm{Fe}^{3+}$ content of bulk composition was estimated on the basis of $P-X_{\mathrm{Fe} 3+}$ and $T-X_{\mathrm{Fe} 3+}$ diagrams. I adopted the $X_{\mathrm{Fe} 3+}$ values for original and fractionated bulk compositions which are similar to reported values from medium- $T$ eclogites and unaltered mid-ocean ridge basalts, respectively. A decrease of the $X_{\mathrm{Fe} 3}+$ values from $\mathrm{M}_{1}$ to $\mathrm{M}_{2}$ suggests fo2 decrease during prograde metamorphism. The eclogites have initially evolved from $\sim 15$ to $20 \mathrm{kbar}$ and $520-570{ }^{\circ} \mathrm{C}\left(\mathrm{M}_{1}\right)$ to $\sim 22-25 \mathrm{kbar}$ and $630-650{ }^{\circ} \mathrm{C}\left(\mathrm{M}_{2}\right)$. The second segment $\left(\mathrm{M}_{3 \mathrm{~A}-\mathrm{B}}\right)$ of prograde $P-T$ path was constrained at $\sim 26 \pm 3$ kbar and $720 \pm$ $80{ }^{\circ} \mathrm{C}$, using the garnet-clinopyroxene-phengite thermobarometer. Further details are available in Kim et al. (2019, J. Metam. Geol.).

Two distinctive $P-T$ trajectories of prograde metamorphism were correlated to episodic growth and/or recrystallization of the zircon mantle and rim domains during two stages of subduction burial at $515.2 \pm 3.9 \mathrm{Ma}(t \sigma)$ and $498.1 \pm 10.8 \mathrm{Ma}(t \sigma)$, respectively. Average burial rates $(<2$ $\mathrm{mm} /$ year $)$ are too low for cold subduction regime $(\sim 5-$ $10{ }^{\circ} \mathrm{C} / \mathrm{km}$ ), suggesting that an exhumation stage intervened between two prograde segments of $P-T$ path. Inherited zircon cores are characterized by the presence of subtle oscillatory zonation and acicular apatite inclusion. The zircon cores are relatively high in $\mathrm{Th} / \mathrm{U}$ ratios $(0.33-0.99)$, and yielded the ${ }^{206} \mathrm{~Pb} /{ }^{238} \mathrm{U}$ ages of $590.9 \pm 5.1 \mathrm{Ma}(t \sigma)$ and $604.8 \pm 4.8 \mathrm{Ma}$ $(t \sigma)$. Hf isotopic compositions of the same analytical pits of $\mathrm{U}-\mathrm{Pb}$ analyses resulted in the initial $\varepsilon_{\mathrm{Hf}}(\mathrm{t})$ values of zircon core ranging from +9.2 to +18.8 . Combined with mildly alkalic, within-plate to continental basalt-like geochemistry, these late Neoproterozoic gabbroic protoliths of the Cambrian eclogites are spatial-temporal equivalent to $c$. $600-580 \mathrm{Ma}$ rift to passive margin magmatic rocks in eastern Australia. 